\title{
Analysis of Leading Sectors in Increasing Economic Growth in the Province of East Nusa Tenggara in 2014-2018
}

\author{
Emilia Khristina Kiha ${ }^{1}$, Frederic Winston Nalle ${ }^{2}$, Gustaf Inyong Kobi ${ }^{3}$ \\ 1,2,3 Faculty of Economics and Business, University of Timor, Indonesia \\ Email: emilia.kiha02@gmail.com
}

\section{Abstract:}

The aims of the study is to find out the leading sectors in increasing economic growth in the province of east nusa tenggara. This study uses secondary data in the form of PDRB data for the 2014-2018 period obtained through literature books, readings related to the problem under study. Sources of data were obtained from government agencies such as the East Nusa Tenggara Province Central Statistics Agency (BPS), as well as related agencies. The result in this study. 1. Based on the results of the Klassen Typology analysis, the sector which is included in the advanced sector and growing rapidly or the leading sector is the sector Mandatory Government Administration, Defense and Social Security. Meanwhile, sectors that are included in the advanced but depressed sector are the Agriculture, Forestry and Fisheries sector, the Construction sector, the Transportation and Warehousing sector, the Information and Communication sector, the Education Services sector, the Health Services sector and Social Activities and the Other Services sector. Sectors classified as potential or still developing sectors are mining and quarrying sector, processing industry sector, electricity and gas supply sector, wholesale and retail trade: car and motorcycle repair and accommodation and food and drink provision sector. Meanwhile, sectors that are relatively lagging behind are the water supply sector, waste management, waste and recycling, the financial services and insurance sector, the real estate sector and the corporate services sector.

Keywords:

leading sectors; increasing; economic growth

\section{Introduction}

Economic development is an important part of national development with the ultimate goal of improving people's welfare, which, among others, can be measured through high real per capita income. According to Rostow in (Jhingan 2014) there are five stages of economic growth, namely: (1) traditional society, (2) prerequisites for take-off, (3) take-off, (4) maturity and (5) mass consumption. One indicator of the success of economic development is the level of economic growth, so it is not surprising that every country or region always pays attention to the rate of economic growth, including Indonesia.

According to Dewi Sondari (2007), a measure of the success of a region's development is to measure the level of economic growth of the region. Economic growth is the process of how an economy develops or changes from time to time. This development process occurs over a long period of time, where there may be a decline or increase in the economy, but in general it shows a tendency to increase the regional economy.

Economic growth can be interpreted as a condition in which an increase in income is caused by an increase in the production of goods and services. According to Bhinadi in (Yuni Purnama, et al, 2017), there are three types of measures to assess economic growth, namely 


\section{Economit Journal: Scientific Journal of Accountancy, Management and Finance ISSN: 2775-5827 (Online), 2775-5819 (Print)}

Vol. 1, No. 1, February 2021, Page: 21-37

Email: economitjournal@gmail.com

output growth, output growth per worker, and per capita output growth. Output growth is used to assess the growth in production capacity which is affected by an increase in labor and capital in the region. Output growth per worker is often used as an indicator of changes in the competitiveness of the region (through productivity growth). Meanwhile, per capita output growth is used as an indicator of changes in economic welfare.

With the enactment of Regional Regulations in Law Number 32 of 2004, every region in Indonesia has now been granted regional autonomy in which the system of government from a centralized system is changed to a decentralized system. Regions should be independent in managing their households in achieving stable economic growth, which is marked by economic development in accordance with their potential and creativity. One of the benchmarks for regional economic development is the regional economic growth. In an effort to increase regional economic growth, it is necessary to know in advance the resources or potential of an area that can be expected to develop optimally. All economic and development activities in each region must be in accordance with the existing potential.

Regional development is currently still prioritizing economic progress. The sophistication of the infrastructure being built, the high economic growth is an example of the success of a development. To achieve this success requires economic growth which continues to increase in a significant direction as seen from the ability of a region to develop its existing potential to meet the needs of its people.

Local governments must participate with the community and by using existing resources must be able to assess the potential of the resources in order to stimulate regional economic growth. According to Sukirno (2006), economic growth is an indicator of successful development. Thus the higher the economic growth usually the higher the welfare of the people, although there are other indicators, namely income distribution.

An economic indicator that is needed to measure the performance of a region's economic growth is Gross Regional Domestic Product (GRDP). GRDP is an important indicator in an area that can identify the totality of net production of goods / services which can then be used as a basis for planning and evaluation of regional development (Evie Erviana, 2020).

The Province of East Nusa Tenggara (NT'T) has a variety of potential resources that are ready to be developed and managed according to availability and factors. The maximum utilization of resources will indirectly increase the economic growth of a region. The main determinant of a region's economic growth is directly related to the demand for goods and services from outside the region (Richardson, 2001). In addition, NTT Province is also one of the provinces in Indonesia which has a lower economic growth rate than the national economic growth rate. For more details regarding the rate of economic growth in the Province of East Nusa Tenggara can be seen in Table 1 below: 
Table 1. Growth Rate of GRDP at Constant Prices 2010

According to Provinces in Indonesia (\%) 2014-2018

\begin{tabular}{|c|c|c|c|c|c|c|}
\hline \multirow[b]{2}{*}{ No. } & \multirow[b]{2}{*}{ Province } & \multicolumn{5}{|c|}{ Economic growth rate } \\
\hline & & 2014 & 2015 & 2016 & $2017 *$ & $\begin{array}{c}2018 \\
* *\end{array}$ \\
\hline 1 & Aceh & 1.55 & -0.73 & 3.29 & 4.18 & 4.61 \\
\hline 2 & North Sumatra & 5.23 & 5,10 & 5.18 & 5,12 & 5.18 \\
\hline 3 & West Sumatra & 5.88 & 5,53 & 5.27 & 5.29 & 5.14 \\
\hline 4 & Riau & 2.71 & 0.22 & 2.18 & 2.68 & 2.34 \\
\hline 5 & Jambi & 7.36 & 4.21 & 4.37 & 4.64 & 4.71 \\
\hline 6 & South Sumatra & 4.79 & 4.42 & 5.04 & 5,51 & 6.04 \\
\hline 7 & Bengkulu & 5.48 & 5.13 & 5.28 & 4.98 & 4.99 \\
\hline 8 & Lampung & 5.08 & 5.13 & 5.14 & 5.16 & 5.25 \\
\hline 9 & Kep. Bangka Belitung & 4.67 & 4.08 & 4.10 & 4.47 & 4.45 \\
\hline 10 & Riau islands & 6.60 & 6,02 & 4.98 & 2.00 & 4.56 \\
\hline 11 & DKI Jakarta & 5.91 & 5.91 & 5.87 & 6.20 & 6.17 \\
\hline 12 & West Java & 5.09 & 5.05 & 5.66 & 5.35 & 5.64 \\
\hline 13 & Central Java & 5.27 & 5.47 & 5.25 & 5.26 & 5.32 \\
\hline 14 & In Yogyakarta & 5.17 & 4.95 & 5.05 & 5.26 & 6.20 \\
\hline 15 & East Java & 5.86 & 5.44 & 5,57 & 5.46 & 5,50 \\
\hline 16 & Banten & 5,51 & 5.45 & 5.28 & 5.73 & 5.81 \\
\hline 17 & Bali & 6.73 & 6.03 & 6.33 & 5,57 & 6.35 \\
\hline 18 & West Nusa Tenggara & 5.17 & 21.76 & 5.81 & 0.12 & -4.56 \\
\hline 19 & East Nusa Tenggara & 5.05 & 4.92 & 5,12 & 5.11 & 5.13 \\
\hline 20 & West Kalimantan & 5.03 & 4.88 & 5.20 & 5.17 & 5.06 \\
\hline 21 & Central Kalimantan & 6.21 & 7.01 & 6.35 & 6.72 & 5.64 \\
\hline 22 & South Kalimantan & 4.84 & 3.82 & 4.40 & 5.28 & 5.13 \\
\hline 23 & East Kalimantan & 1.71 & -1.20 & -0.38 & 3.13 & 2.67 \\
\hline 24 & North Kalimantan & 8.18 & 3.40 & 3.75 & 6.59 & 6.04 \\
\hline 25 & North Sulawesi & 6.31 & 6.12 & 6.16 & 6.31 & 6.01 \\
\hline 26 & Central Sulawesi & 5.07 & 15.50 & 9.94 & 7,10 & 6.30 \\
\hline 27 & South Sulawesi & 7.54 & 7,19 & 7.42 & 7.21 & 7.07 \\
\hline 28 & Southeast Sulawesi & 6.26 & 6.88 & 6.51 & 6.76 & 6.42 \\
\hline 29 & Gorontalo & 7.27 & 6.22 & 6.52 & 6.73 & 6.51 \\
\hline 30 & West Sulawesi & 8.86 & 7.31 & 6.01 & 6.62 & 6.23 \\
\hline 31 & Maluku & 6.64 & 5.48 & 5.73 & 5.82 & 5.94 \\
\hline 32 & North Maluku & 5.49 & 6.10 & 5.77 & 7.67 & 7.92 \\
\hline 33 & West Papua & 5.38 & 4.15 & 4.52 & 4.01 & 6.24 \\
\hline 34 & Papua & 3.65 & 7.35 & 9,14 & 4.64 & 7.33 \\
\hline & INDONESIA & 5.21 & 4.99 & 5.16 & 5.23 & 5.31 \\
\hline
\end{tabular}

Source: Indonesian Statistics 2018 and 2019

Note: *: Preliminary figures

$* *$ : Figures are very provisional

Based on the table of economic growth rates for each province in Indonesia, it explains that in 2018 NTT Province was in the 22nd position, namely $(5.13 \%)$ and the first was North Maluku Province (7.92\%). Meanwhile, the rate of economic growth in NTT Province from 2014-2018 has fluctuated or fluctuated, namely in 2014 (5.05\%), decreased in $2015(4.92 \%)$, in 2016 increased by (5.12\%) \%), and in 2017 it decreased again to (5.11\%), and 
in 2018 the Economic Growth of NTT Province increased to (5.13\%). While seen from the growth rate of NTT Province, it is still below Indonesia's growth rate, namely in 2018 the economic growth rate of NTT Province was 5.

The calculation of the 17 sectors will determine the economic condition of a region. Of the 17 sectors, the agricultural sector has the largest role in the total GRDP of NTT Province because most of the population works as farmers. For more details regarding the contribution of GRDP at constant 2010 prices according to business fields can be seen in Table 2 below:

Table 2. Contribution of the Economic Sector at Constant Prices 2010 against PDRB East Nusa Tenggara Province (Billion Rupiah) 2014-2018

\begin{tabular}{|c|c|c|c|c|c|c|c|}
\hline \multirow[t]{2}{*}{ No } & \multirow{2}{*}{$\begin{array}{l}\text { GRDP According to } \\
\text { Business field }\end{array}$} & \multicolumn{5}{|c|}{ Year } & \multirow{2}{*}{ total } \\
\hline & & 2014 & 2015 & 2016 & $2017 *$ & $2018 * *$ & \\
\hline 1. & $\begin{array}{l}\text { Agriculture, Forestry and } \\
\text { Fisheries }\end{array}$ & $15,614.0$ & $16,123.2$ & $16,512.7$ & $17,342.0$ & $17,875.7$ & $83,467.6$ \\
\hline 2. & Mining \& Excavation & 794.6 & 833.0 & 877.8 & 894.4 & 913.3 & $4,313.1$ \\
\hline 3. & Processing industry & 674.6 & 709.9 & 745.2 & 800.1 & 841.4 & 771.2 \\
\hline 4. & $\begin{array}{l}\text { Procurement of Electricity } \\
\text { and Gas }\end{array}$ & 35.8 & 40.9 & 46.9 & 47.2 & 51.7 & 222.5 \\
\hline 5. & $\begin{array}{l}\text { Water Supply, Waste } \\
\text { Management, Waste and } \\
\text { Recycling }\end{array}$ & 39.2 & 40.0 & 40.1 & 40.7 & 42.9 & 202.9 \\
\hline 6. & Construction & $5,733.4$ & $5,985.1$ & $6,443.6$ & $6,819.2$ & $7,254.9$ & 36.2 \\
\hline 7. & $\begin{array}{l}\text { Wholesale and Retail Trade: } \\
\text { Auto Repair } \\
\text { and Motorbikes }\end{array}$ & $6,121.6$ & $6,493.3$ & $6,933.2$ & $7,241.4$ & $7,772.4$ & $34,561.9$ \\
\hline 8. & $\begin{array}{l}\text { Transportation } \\
\text { Warehousing } \\
\end{array}$ & $2,702.3$ & $2,852.9$ & $3,036.4$ & $3,269.0$ & $3,527.9$ & $15,388.5$ \\
\hline 9. & $\begin{array}{l}\text { Provision of } \\
\text { Accommodation and Food } \\
\text { and Drink }\end{array}$ & 318.3 & 337.9 & 386.8 & 439.3 & 492.8 & $1,975.1$ \\
\hline 10. & $\begin{array}{l}\text { Information and } \\
\text { Communication }\end{array}$ & $4,595.3$ & $4,923.6$ & $5,256.3$ & $5,524.3$ & $5,794.3$ & $26,093.8$ \\
\hline 11. & $\begin{array}{lll}\text { Financial } & \text { Services } & \text { and } \\
\text { Insurance } & & \end{array}$ & $2,058.3$ & $2,176.8$ & $2,361.1$ & $2,500.3$ & $2,585.8$ & $11,682.3$ \\
\hline 12. & Real Estate & $1,402.8$ & $1,456.8$ & $1,506.5$ & $1,581.2$ & $1,657.9$ & $7,605.2$ \\
\hline 13. & Company Services & 157.7 & 165.0 & 169.7 & 172.1 & 175.0 & 839.5 \\
\hline 14. & $\begin{array}{l}\text { Mandatory Government } \\
\text { Administration, Defense } \\
\text { and Social Security }\end{array}$ & $6,785.7$ & $7,248.1$ & $7,656.4$ & $7,883.2$ & $8,468.8$ & $38,042.2$ \\
\hline 15. & Education Services & $4,753.5$ & $4,956.2$ & $5,159.1$ & $5,441.2$ & $5,572.4$ & $25,882.4$ \\
\hline 16. & $\begin{array}{l}\text { Health Services and Social } \\
\text { Activities }\end{array}$ & 1,1 & $1,212.3$ & $1,287.4$ & $1,382.0$ & $1,480.3$ & $6,510.8$ \\
\hline 17. & Other Services & $1,172.2$ & $1,215.8$ & $1,258.9$ & $1,347.0$ & $1,434.0$ & $6,427.9$ \\
\hline & 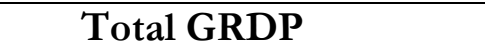 & $54,108.0$ & & & $02,124.1$ & 941.4 & $99,222.9$ \\
\hline
\end{tabular}

Source: NTT Provincial Statistics Agency in 2018 and 2019

Note: *: Preliminary figures

$* *$ : Figures are very provisional 
Based on the table of the contribution of each sector to GRDP above, The sectors that have the biggest contribution are the agriculture, forestry and fisheries sectorswith a number in 2014-2018 amounting to 15614.0 (billion) - 17875.7 (billion), and that is in second place, namely the Government Administration, Defense and Compulsory Social Security sector, namely from 2014-2018 of 6785,7 (billion) - 8468.8 (billion), and that is in the third place, namely the Wholesale and Retail Trade sector: Car and Motorcycle Repair, namely from 20142018 amounting to 6121.6 (billion) - 7772.4 (billion). Meanwhile, in other sectors, the contribution value to GRDP is still below the three sectors whose value is greater.

Although the agriculture, forestry and fisheries sectors have the largest contribution to the GRDP of East Nusa Tenggara Province, from year to year they are not supported by their growth rate. In fact, the economic growth rate of the agricultural, forestry and fisheries sectors is smaller than the economic growth rates of other sectors. For more details regarding the rate of economic growth for each sector can be seen in Table 3 below:

Table 3. Economic Sector Growth Rate at Constant Prices 2010 East Nusa Tenggara Province (\%) 2014-2018

\begin{tabular}{|c|c|c|c|c|c|c|}
\hline No. & \multirow{2}{*}{$\begin{array}{l}\text { GRDP According to } \\
\text { Business field }\end{array}$} & \multicolumn{5}{|c|}{ Year } \\
\hline & & 2014 & 2015 & 2016 & $2017 *$ & $2018^{* *}$ \\
\hline 1. & $\begin{array}{l}\text { Agriculture, Forestry and } \\
\text { Fisheries }\end{array}$ & 3.61 & 3.26 & 2.42 & 5.02 & 3.08 \\
\hline 2. & Mining \& Excavation & 7.28 & 4.83 & 5.38 & 1.89 & 2.11 \\
\hline 3. & Processing industry & 3.37 & 5.23 & 4.98 & 7.36 & 5.16 \\
\hline 4. & $\begin{array}{l}\text { Procurement of Electricity and } \\
\text { Gas }\end{array}$ & 19.89 & 14.37 & 14.61 & 0.70 & 9,57 \\
\hline 5. & 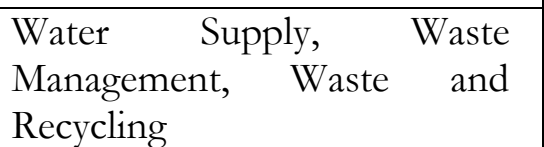 & 4.82 & 2.07 & 0.38 & 1.43 & 5.47 \\
\hline 6. & Construction & 5.20 & 4.39 & 7.66 & 5.83 & 6.39 \\
\hline 7. & $\begin{array}{l}\text { Wholesale and Retail Trade: } \\
\text { Auto Repair and Motorbikes }\end{array}$ & 5.08 & 6,07 & 6.77 & 4.45 & 7.33 \\
\hline 8. & Transportation and Warehousing & 6.55 & 5,57 & 6.43 & 7.66 & 7.92 \\
\hline 9. & $\begin{array}{l}\text { Provision of Accommodation } \\
\text { and Food and Drink }\end{array}$ & 6.25 & 6.17 & 14.46 & 13.59 & 12.16 \\
\hline 10. & Information and Communication & 7.65 & 7,14 & 6.76 & 5,10 & 4.89 \\
\hline 11. & Financial Services and Insurance & 6.44 & 5.76 & 8.47 & 5.89 & 3.42 \\
\hline 12. & Real Estate & 1.43 & 3.85 & 3.41 & 4.96 & 4.85 \\
\hline 13. & Company Services & 4.90 & 4.61 & 2.8 & 1.43 & 1.67 \\
\hline 14. & $\begin{array}{l}\text { Mandatory } \begin{array}{l}\text { Government } \\
\text { Administration, Defense and } \\
\text { Social Security }\end{array} \\
\end{array}$ & 5.93 & 6.81 & 5.63 & 2.96 & 7.43 \\
\hline 15. & Education Services & 5.86 & 4.27 & 4.09 & 5.47 & 2.41 \\
\hline 16. & $\begin{array}{l}\text { Health Services and Social } \\
\text { Activities }\end{array}$ & 3.67 & 5,52 & 6.19 & 7.36 & 7,11 \\
\hline 17. & Other Services & 4.38 & 3.72 & 3.55 & 6.99 & 6.47 \\
\hline & Total GRDP & 5.05 & 4.92 & 5,12 & 5.11 & 5.13 \\
\hline
\end{tabular}

Source: NTT Provincial Statistics Agency in 2018 and 2019

Note: *: Preliminary figures

$* *$ : Figures are very provisional 
Based on the table of growth rates for each sector above, it is clear that although the contribution of the agriculture, forestry and fisheries sectors to NTT Province's GRDP is very large, the growth rate is very small compared to other sectors. The growth rate fluctuates, namely in 2014 amounted to $3.61 \%$, decreased in 2015 by 3.26\% and decreased again in 2016 namely $2.42 \%$, in 2017 increased by $5.02 \%$, and in 2018 experienced a decline of $3.08 \%$, however the agriculture, forestry and fisheries sectors were the largest contributors to NTT Province's GRDP.

\section{Research Methods}

\subsection{Research Location}

This research was conducted in the Province of East Nusa Tenggara as one of the provinces in Indonesia with the consideration that the results of this research are in the form of potential leading sectors to be used as information and as a consideration for the policies of the East Nusa Tenggara Provincial Government in increasing economic growth.

\subsection{Types and Sources of Data}

This study uses secondary data in the form of PDRB data for the 2014-2018 period obtained through literature books, readings related to the problem under study. Sources of data were obtained from government agencies such as the East Nusa Tenggara Province Central Statistics Agency (BPS), as well as related agencies.

\section{Results and Discussion}

\subsection{Results of Analysis and Discussion}

The results of the analysis and discussion will answer the problem formulations in this study. To answer the problem formulation in this study, the analytical tools used are Klassen Typology analysis, Location Quotient and Shift Share.

\section{a. Klassen Typology Analysis Results}

Typology Klassen method is used to determine the leading sectors by grouping economic sectors in the province of East Nusa Tenggara according to their growth structure. By using the Klassen Mattrix, four sector groupings can be carried out by utilizing the growth rate and contribution value.

Following are the results of data processing, namely the average growth rate and the average contribution of each economic sector to Indonesia's GDP and East Nusa Tenggara Province GDP in 2014-2018 as follows:

Table 4. Growth Rate and Contribution of the Economic Sector toIndonesian GDP and NTT Province GRDP 2014-2018

\begin{tabular}{|c|c|c|c|c|}
\hline \multirow[b]{2}{*}{$\begin{array}{c}\text { Economic Sector by Business } \\
\text { Field }\end{array}$} & \multicolumn{2}{|c|}{ Indonesia } & \multicolumn{2}{|c|}{ NTT Province } \\
\hline & $\begin{array}{c}\text { Average Rate } \\
\text { Growth } \\
\text { (S) }\end{array}$ & \begin{tabular}{|c|} 
Average \\
Contribution \\
$(\mathrm{Sk})$ \\
\end{tabular} & $\begin{array}{c}\text { Average Rate } \\
\text { Growth } \\
(\mathrm{Si})\end{array}$ & \begin{tabular}{|c|} 
Average \\
Contribution \\
$($ Ski $)$
\end{tabular} \\
\hline $\begin{array}{l}\text { Agriculture, Forestry and } \\
\text { Fisheries }\end{array}$ & 3.83 & 13.31 & 3.48 & 27.94 \\
\hline Mining \& Excavation & 0.15 & 8.60 & 4.30 & 1.44 \\
\hline Processing industry & 4.36 & 22.12 & 5.22 & 1.26 \\
\hline $\begin{array}{l}\text { Procurement of Electricity } \\
\text { and Gas }\end{array}$ & 3.84 & 1.09 & 11.84 & 0.07 \\
\hline
\end{tabular}




\begin{tabular}{|l|c|c|c|c|}
\hline $\begin{array}{l}\text { Water Supply, Waste } \\
\text { Management, Waste and } \\
\text { Recycling }\end{array}$ & 5.19 & 0.08 & 2.80 & 0.07 \\
\hline Construction and Retail & 6.29 & 10.20 & 5.89 & 10.76 \\
\hline $\begin{array}{l}\text { Wholesale and } \\
\text { Trade: Car and Motorcycle } \\
\text { Repair }\end{array}$ & 4.23 & 13.86 & 5.94 & 11.54 \\
\hline $\begin{array}{l}\text { Transportation } \\
\text { Warehousing }\end{array}$ & 7.40 & 4.13 & 6.83 & 5.13 \\
\hline $\begin{array}{l}\text { Provision an } \\
\text { Accommodation and Food } \\
\text { and Drink }\end{array}$ & 5.26 & 3.11 & 10.52 & 0.65 \\
\hline $\begin{array}{l}\text { Information and } \\
\text { Communication }\end{array}$ & 6.36 & 4.06 & 5.99 & 3.90 \\
\hline $\begin{array}{l}\text { Financial Services and } \\
\text { Insurance }\end{array}$ & 4.21 & 3.05 & 3.70 & 2.54 \\
\hline Real Estate & 8.39 & 1.76 & 3.10 & 0.28 \\
\hline Company Services & 3.86 & 3.51 & 5.75 & 12.71 \\
\hline $\begin{array}{l}\text { Mandatory Government } \\
\text { Administration, Defense } \\
\text { and Social Security }\end{array}$ & 5.14 & 3.21 & 4.42 & 8.66 \\
\hline Education Services & 6.75 & 1.13 & 5.97 & 2.17 \\
\hline $\begin{array}{l}\text { Health Services and Social } \\
\text { Activities }\end{array}$ & 1.73 & 5.02 & 2.15 \\
\hline Other Services & Source: Processed secondary data in 2020 & & 8.71 \\
\hline
\end{tabular}

Based on Table 4 above, the sector that has the highest average growth rate of the NTT Province's GRDP is the sectorProcurement of Electricity and Gas followed by sector Provision of Accommodation and Food and Drink, while the sector that has the smallest average growth rate is the sector Water Supply, Waste Management, Waste and Recycling. For the largest average contribution to the GRDP of NTT Province is the sectorAgriculture, Forestry and Fisheries then followed by sector Mandatory Government Administration, Defense and Social Security, meanwhile, the smallest average contribution is the sector of electricity and gas procurement and the sector of water supply, waste management, waste and recycling.

Furthermore, through the data in Table 4 above, the economic sector can be classified into four quadrants and can find out which sectors are the leading sectors in the NTT Province in 2014-2018 based on Klassen Typology in Table 5 below: 
Table 5. NTT Province GRDP Sector Classification 2014-2018 based on Klassen Typology

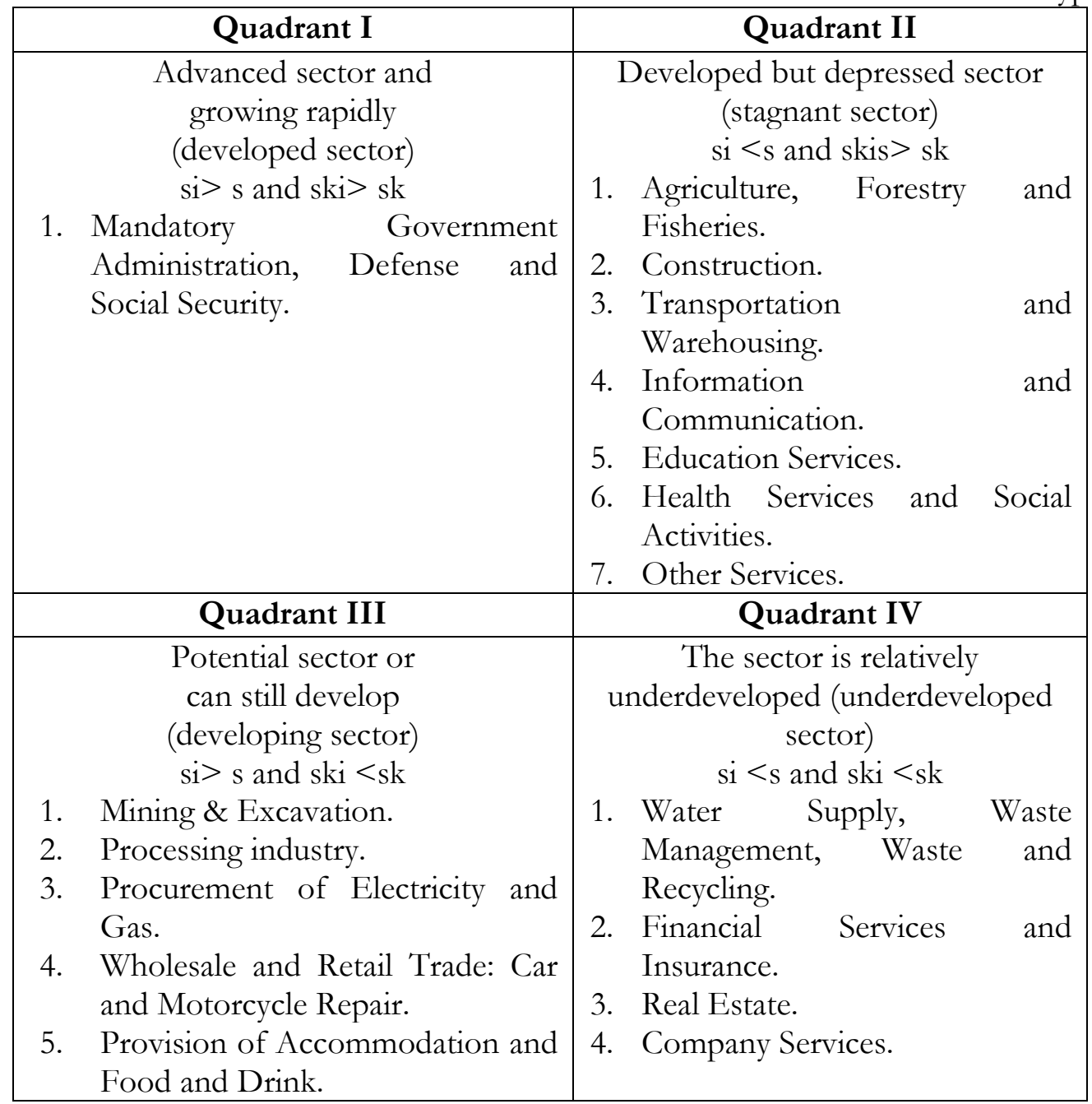

Source: Processed secondary data in 2020

In accordance with the results of the analysis in Table 4.2 Classification of the NTT Province's GRDP Sector in 2014-2018 based on Klassen Typology, a sector that is included in the advanced and rapidly growing sector or quadrant I, namely the sectorMandatory Government Administration, Defense and Social Security. Meanwhile, sectors included in the advanced but depressed sector or quadrant II are the agriculture, forestry and fisheries sector, the construction sector, the transportation and warehousing sector, the information and communication sector, the education services sector, the health services sector and social activities and other services sectors. Sectors that are classified as potential or still developing sectors or quadrant III, namely the mining and quarrying sector, the manufacturing sector, the electricity and gas supply sector, the wholesale and retail trade sector: car and motorcycle repair and the provision of accommodation and food and drink sector, meanwhile sectors that are relatively underdeveloped or quadrant IV are the water supply sector, waste management, waste and recycling, the financial services and insurance sector, the real estate sector and the corporate services sector.

\section{b. Location Quotient Analysis Results}

The Location Quotient value is used to determine the basis and non-basis sectors in East Nusa Tenggara Province. The base sector is a sector that is able to meet the needs of its own region / territory and is able to export outside the region. The base sector can also be 
used as a sector that will encourage the growth of other sectors which will have an impact on the creation of labor.

Following are the results of data processing, namely the Location Quotient value of the contribution of each sector to Indonesia's PBD and East Nusa Tenggara Province GRDP 2014-2018 in table 6 below:

Table 6. Results of the 2014-2018 LQ Value Calculation for East Nusa Tenggara Province

\begin{tabular}{|l|c|c|c|c|c|c|}
\hline \multirow{2}{*}{ Economic Sector by Business Field } & \multicolumn{5}{c|}{ LQ VALUE } & \multirow{2}{*}{ Ket } \\
\cline { 2 - 6 } & $\mathbf{2 0 1 4}$ & $\mathbf{2 0 1 5}$ & $\mathbf{2 0 1 6}$ & $\mathbf{2 0 1 7}$ & $\mathbf{2 0 1 8}$ & \\
\hline Agriculture, Forestry and Fisheries & 2.19 & 2.18 & 2.16 & 2.18 & 2.16 & Base \\
\hline Mining \& Excavation & 0.16 & 0.17 & 0.18 & 0.18 & 0.18 & Non Base \\
\hline Processing industry & 0.06 & 0.06 & 0.06 & 0.06 & 0.06 & Non Base \\
\hline Procurement of Electricity and Gas & 0.06 & 0.07 & 0.07 & 0.07 & 0.08 & Non Base \\
\hline $\begin{array}{l}\text { Water Supply, Waste Management, } \\
\text { Waste and Recycling }\end{array}$ & 0.90 & 0.86 & 0.83 & 0.81 & 0.81 & Non Base \\
\hline Construction & 1.10 & 1.08 & 1.10 & 1.09 & 1.09 & Base \\
\hline $\begin{array}{l}\text { Wholesale and Retail Trade; Car and } \\
\text { Motorcycle Repair }\end{array}$ & 0.82 & 0.85 & 0.87 & 0.87 & 0.89 & Non Base \\
\hline Transportation and Warehousing & 1.31 & 1.29 & 1.28 & 1.27 & 1.28 & Base \\
\hline $\begin{array}{l}\text { Provision of Accommodation and Food } \\
\text { and Drink }\end{array}$ & 0.20 & 0.20 & 0.22 & 0.23 & 0.25 & Non Base \\
\hline Information and Communication & 1.89 & 1.85 & 1.81 & 1.73 & 1.70 & Base \\
\hline Financial Services and Insurance & 1.02 & 0.99 & 0.99 & 0.99 & 0.98 & Non Base \\
\hline Real Estate & 0.87 & 0.86 & 0.85 & 0.86 & 0.87 & Non Base \\
\hline Company Services & 0.18 & 0.18 & 0.17 & 0.16 & 0.15 & Non Base \\
\hline $\begin{array}{l}\text { Mandatory Government } \\
\text { Administration, Defense and Social } \\
\text { Security }\end{array}$ & 3.62 & 3.70 & 3.78 & 3.81 & 3.83 & Base \\
\hline Education Services & 2.85 & 2.77 & 2.78 & 2.82 & 2.74 & Base \\
\hline Health Services and Social Activities & 1.99 & 1.97 & 1.99 & 1.99 & 1.99 & Base \\
\hline Other Services & 1.38 & 1.33 & 1.27 & 1.25 & 1.22 & Base \\
\hline
\end{tabular}

Source: Processed secondary data in 2020

Based on table 6, the calculation of the 2014-2018 LQ value of NTT Province above, it can be seen that the Agriculture, Forestry and Fisheries sector, the Construction sector, the Transportation and Warehousing sector, the Information and Communication sector, the Government Administration sector, the Compulsory Defense and Social Security sector, the Education Services sector., the Health Services and Social Activities sector and the Other Services sector are the base sectors in East Nusa Tenggara Province. These sectors are the basic sectors, which means that these sectors are able to meet the needs of their own regions / regions and are able to export to other regions. These sectors are very good to be developed and can encourage other sectors to develop and can be a resource to boost the economy of East Nusa Tenggara Province. 


\section{c. Results of Shift Share Analysis}

Basically, Shift Share analysis is used to see changes in total employment or total GRDP of an analysis area based on the Shift component and its Share component based on a certain period according to the time used. This analysis is used to determine how much the change in the total GRDP of NTT Province when viewed from the Shift and Share components. The Share component is the value of the National Share (Ns), which is a component that shows the number of changes in the Province's GRDP if the proportion of changes is the same as the rate of national increase during the 2014-2018 period. Meanwhile, the Shift component is the deviation from the National Share in the growth of the GRDP value in NTT Province which can be seen from the value of the Proportional Share and Differential Shift components.

$$
\Delta \mathrm{E} r, \mathrm{i}, \mathrm{t}=(\mathrm{Ns}, \mathrm{i}+\operatorname{Pr}, \mathrm{i}+\operatorname{Dr}, \mathrm{i})
$$

To find out the development or change in the value of each economic sector against the GRDP of NTT Province between 2014 and 2018, as a comparison, National GDP data is used for the same period, it can be seen in table 7 below:

Table 7. Results of the calculation of the Shift Share Value of East Nusa Tenggara Province 2014-2018

\begin{tabular}{|c|c|c|c|c|c|c|}
\hline \multirow{3}{*}{$\begin{array}{l}\text { Economic Sector by } \\
\text { Business Field }\end{array}$} & \multicolumn{3}{|c|}{ Indonesian GDP (Trillion Rupiah) } & \multicolumn{3}{|c|}{$\begin{array}{l}\text { NTT Province GRDP } \\
\text { (billion Rupiah) }\end{array}$} \\
\hline & 2014 & 2018 & \multirow{2}{*}{$\Delta \mathrm{E} \mathrm{N}, \mathrm{i}, \mathrm{t}$} & 2014 & 2018 & \multirow{2}{*}{$\Delta \mathrm{Er}$} \\
\hline & $\mathrm{EN}, \mathrm{i}, \mathrm{tn}$ & $\mathrm{EN}, \mathrm{i}, \mathrm{t}$ & & $\begin{array}{c}\text { Er, i, } \\
\text { tn }\end{array}$ & Er, $\mathrm{i}, \mathrm{t}$ & \\
\hline $\begin{array}{l}\text { Agriculture, Forestry and } \\
\text { Fisheries }\end{array}$ & $11,29,052.7$ & $13,07,025.7$ & $1,77,973.0$ & $15,614.0$ & $17,875.7$ & $2,261.7$ \\
\hline Mining and excavation & $7,94,489.5$ & $7,96,505.0$ & $2,015.5$ & 794.6 & 913.3 & 118.7 \\
\hline Processing industry & $18,54,256.7$ & $21,93,266.4$ & $3,39,009.7$ & 674.6 & 841.4 & 166.8 \\
\hline $\begin{array}{l}\text { Procurement of } \\
\text { Electricity and Gas }\end{array}$ & $94,047.2$ & $1,07,108.6$ & $13,061.4$ & 35.8 & 51.7 & 15.9 \\
\hline $\begin{array}{l}\text { Water Supply, Waste } \\
\text { Management, Waste and } \\
\text { Recycling }\end{array}$ & $6,882.5$ & $8,421.8$ & $1,539.3$ & 39.2 & 42.9 & 3.7 \\
\hline Construction & $8,26,615.6$ & $10,48,082.8$ & $2,21,467.2$ & $5,733.4$ & $7,254.9$ & $1,521.5$ \\
\hline $\begin{array}{l}\text { Wholesale and Retail } \\
\text { Trade; Car and } \\
\text { Motorcycle Repair } \\
\end{array}$ & $11,77,297.5$ & $13,76,937.4$ & 1,99,639.9 & $6,121.6$ & $7,772.4$ & $1,650.8$ \\
\hline $\begin{array}{l}\text { Transportation and } \\
\text { Warehousing }\end{array}$ & $3,26,933.0$ & $4,35,185.3$ & $1,08,252.3$ & $2,702.3$ & $3,527.9$ & 825.6 \\
\hline $\begin{array}{l}\text { Provision of } \\
\text { Accommodation and } \\
\text { Food and Drink }\end{array}$ & $2,57,815.5$ & $3,14,955.2$ & $57,139.7$ & 318.3 & 492.8 & 174.5 \\
\hline $\begin{array}{l}\text { Information and } \\
\text { Communication }\end{array}$ & $3,84,475.6$ & $5,38,874.6$ & 1,54,399.0 & $4,595.3$ & $5,794.3$ & 1,199.0 \\
\hline $\begin{array}{l}\text { Financial Services and } \\
\text { Insurance }\end{array}$ & $3,19,825.5$ & $4,15,579.1$ & $95,753.6$ & $2,058.3$ & $2,585.8$ & 527.5 \\
\hline Real Estate & $2,56,440.2$ & $3,00,106.7$ & $43,666.5$ & $1,402.8$ & $1,657.9$ & 255.1 \\
\hline
\end{tabular}




\begin{tabular}{|l|r|r|r|r|r|r|} 
Company Services & $1,37,795.3$ & $3,00,106.7$ & $1,62,311.4$ & 157.7 & 175.0 & 17.3 \\
\hline $\begin{array}{l}\text { Mandatory Government } \\
\text { Administration, Defense } \\
\text { and Social Security }\end{array}$ & $2,96,329.7$ & $3,49,506.6$ & $53,176.9$ & $6,785.7$ & $8,468.8$ & $1,683.1$ \\
\hline Education Services & $2,63,685.0$ & $3,21,083.6$ & $57,398.6$ & $4,753.5$ & $5,572.4$ & 818.9 \\
\hline $\begin{array}{l}\text { Health Services and } \\
\text { Social Activities }\end{array}$ & $91,357.1$ & $1,17,314.9$ & $25,957.8$ & $1,148.8$ & $1,480.3$ & 331.5 \\
\hline Other services & $1,34,070.1$ & $1,85,468.9$ & $51,398.8$ & $1,172.2$ & $1,434.0$ & 261.8 \\
\hline \multicolumn{1}{|c|}{ TOTAL } & $83,51,368.7$ & $1,01,15,529.3$ & $17,64,160.6$ & $54,108.0$ & $65,941.4$ & $11,833.4$ \\
\hline
\end{tabular}

Source: Processed secondary data in 2020

Where:

1. $\mathbf{E N}, \mathbf{i}, \mathbf{t n}$ is the number of values of a sector in Indonesia's GDP in the base year (tn) or early 2014.

2. EN, $\mathbf{i}, \mathbf{t}$ is the number of values of a sector in Indonesia's GDP at the end of $(t) 2018$.

3. Er, $\mathbf{i}$, th is the value of a sector in the NTT Province GRDP in the base year (tn) or early 2014.

4. Er, $\mathbf{i}, \mathbf{t}$ is the value of a sector in the NTT Province GRDP in the final year (t) 2018.

5. $\Delta \mathbf{E} \mathbf{N}, \mathbf{i}, \mathbf{t}$ is the amount of change in the value of a sector in Indonesia's GDP from the final year (t) 2018 with the base year or early (tn) 2014. Formulated, $\Delta \mathrm{E} \mathrm{N}, \mathrm{i}, \mathrm{t}=\mathrm{EN}, \mathrm{i}, \mathrm{t}-$ $\mathrm{EN}, \mathrm{i}, \mathrm{tn}$.

6. $\Delta \mathbf{E} \mathbf{r}, \mathbf{i}, \mathrm{t}$ is the magnitude of the change in the value of a sector in the NT'T Province's GRDP from the final year ( $t$ ) 2018 with the base year or the beginning (tn) 2014. Formulated, $\Delta \mathrm{E} \mathrm{r}, \mathrm{i}, \mathrm{t}=\mathrm{E} \mathrm{r}, \mathrm{i}, \mathrm{t}-\mathrm{E} \mathrm{r}, \mathrm{i}, \mathrm{tn}$.

7. EN, $\mathbf{t n}$ is the total value of all Indonesian GDP in the base year (tn) 2014.

8. $\mathbf{E N}, \mathbf{t}$ is the total value of all Indonesian GDP at the end of ( $\mathrm{t}) 2018$.

9. Er, $\mathbf{m r}$ is the total value of all NTT Province GRDP in the base year (tn) 2014. $\backslash$

10. $\mathbf{E r}, \mathbf{t}$ is the total value of all NTT Province GRDP in the final year ( $\mathrm{t}) 2018$.

After analyzing the rate of change in Indonesia's GDP and NTT Province's GDP, the next step is to determine the value and component of the National Share.

\section{Calculation of National Share (Ns)}

The National Share component shows the amount of value added in a sector of GRDP of NTT Province if the proportion of changes is the same as the rate of national added during the 2014-2018 period. The following is the result of the processed data for the National Share value in table 8 below:

Table 8. The results of the 2014-2018 NT'T Province National Share (Ns) Value Calculation

\begin{tabular}{|c|c|c|c|c|}
\hline \multirow{2}{*}{$\begin{array}{l}\text { Economic Sector by } \\
\text { Business Field }\end{array}$} & Er, $i$, tn & $\begin{array}{l}E N, t / \\
E N, t n\end{array}$ & (a) $\times(b)$ & $\begin{array}{l}\text { National } \\
\text { Share }\end{array}$ \\
\hline & (a) & (b) & (c) & (c) - (a) \\
\hline $\begin{array}{l}\text { Agriculture, Forestry and } \\
\text { Fisheries }\end{array}$ & $15,614.0$ & 1.21 & $18,912.3$ & $3,298.3$ \\
\hline Mining and excavation & 794.6 & 1.21 & 962.5 & 167.9 \\
\hline Processing industry & 674.6 & 1.21 & 817.1 & 142.5 \\
\hline $\begin{array}{l}\text { Procurement of Electricity } \\
\text { and Gas }\end{array}$ & 35.8 & 1.21 & 43.4 & 7.6 \\
\hline
\end{tabular}




\begin{tabular}{|c|c|c|c|c|}
\hline $\begin{array}{l}\text { Water Supply, Waste } \\
\text { Management, Waste and } \\
\text { Recycling }\end{array}$ & 39.2 & 1.21 & 47.5 & 8.3 \\
\hline Construction & $5,733.4$ & 1.21 & $6,944.5$ & $1,211.1$ \\
\hline $\begin{array}{l}\text { Wholesale and Retail Trade; } \\
\text { Car and Motorcycle Repair }\end{array}$ & $6,121.6$ & 1.21 & $7,414.7$ & $1,293.1$ \\
\hline $\begin{array}{l}\text { Transportation and } \\
\text { Warehousing }\end{array}$ & $2,702.3$ & 1.21 & $3,273.1$ & 570.8 \\
\hline $\begin{array}{l}\text { Provision of } \\
\text { Accommodation and Food } \\
\text { and Drink }\end{array}$ & 318.3 & 1.21 & 385.5 & 67.2 \\
\hline $\begin{array}{l}\text { Information and } \\
\text { Communication }\end{array}$ & $4,595.3$ & 1.21 & $5,566.0$ & 970.7 \\
\hline $\begin{array}{l}\text { Financial Services and } \\
\text { Insurance }\end{array}$ & $2,058.3$ & 1.21 & $2,493.1$ & 434.8 \\
\hline Real Estate & $1,402.8$ & 1.21 & $1,699.1$ & 296.3 \\
\hline Company Services & 157.7 & 1.21 & 191.0 & 33.3 \\
\hline $\begin{array}{l}\text { Mandatory Government } \\
\text { Administration, Defense } \\
\text { and Social Security }\end{array}$ & $6,785.7$ & 1.21 & $8,219.1$ & $1,433.4$ \\
\hline Education Services & $4,753.5$ & 1.21 & $5,757.6$ & $1,004.1$ \\
\hline $\begin{array}{l}\text { Health Services and Social } \\
\text { Activities }\end{array}$ & $1,148.8$ & 1.21 & $1,391.5$ & 242.7 \\
\hline Other services & $1,172.2$ & 1.21 & $1,419.8$ & 247.6 \\
\hline TOTAL & $54,108.0$ & 20.59 & 65538.01 & 11429.91 \\
\hline
\end{tabular}

Source: Processed Secondary Data in 2020

Based on the calculation of the value of the National Share in table 4.5 above, it shows the value added of the NTT Province's GRDP with the proportion of the increase in Indonesia's GDP. The sector that has the largest National Share value is the Agriculture, Forestry and Fisheries sector, namely 3,298.3, while the smallest value is the Water Supply, Waste Management, Waste and Recycling sector, namely 8.3

After calculating the National Share value, the next step is to determine the Proportional Shift value which can show the amount of deviation or deviation from the National Share value.

\section{Proportional Shift $(\mathbb{P})$ calculation}

Proportional Shiftshows the value of the structural component or industrial mix (industrial mix). A positive Proportional Shift value indicates these regions are specialized in sectors that are growing faster nationally. Negative values indicate otherwise. This component looks at the effect of sector-I nationally on the growth of sector-i employment in the region being analyzed.Following is the result of the Proportional Shift value data processing in table 9 below: 
Table 9. The results of the calculation of the Proportional Shift (P) Value of NTT Regency in 2014-2018

\begin{tabular}{|c|c|c|c|c|c|}
\hline \multirow{2}{*}{$\begin{array}{c}\text { Economic Sector by } \\
\text { Business Field }\end{array}$} & Er, i, tn & EN, $, \mathrm{i}, \mathrm{t} / \mathrm{EN}, \mathrm{i}, \mathrm{tn}$ & $\underset{\text { tn }}{E N, t ~ E N, ~}$ & (b) - (c) & $\begin{array}{c}\text { Proportional } \\
\text { Shift }\end{array}$ \\
\hline & (a) & (b) & (c) & (d) & (a) $\times(d)$ \\
\hline $\begin{array}{l}\text { Agriculture, Forestry and } \\
\text { Fisheries }\end{array}$ & $15,614.0$ & 1.16 & 1.21 & -0.05 & (1.t \\
\hline Mining and excavation & 794.6 & 1.00 & 1.21 & -0.21 & 165.84 \\
\hline Processing industry & 674.6 & 1.18 & 1.21 & -0.03 & 19.17 \\
\hline $\begin{array}{l}\text { Procurement of } \\
\text { Electricity and Gas }\end{array}$ & 35.8 & 1.14 & 1.21 & -0.07 & \\
\hline $\begin{array}{l}\text { Water Supply, Waste } \\
\text { Management, Waste and } \\
\text { Recycling }\end{array}$ & 39.2 & 1.22 & 1.21 & 0.01 & 0.49 \\
\hline Construction & $5,733.4$ & 1.27 & 1.21 & 0.06 & 324.96 \\
\hline $\begin{array}{l}\text { Wholesale and Retail } \\
\text { Trade; Car and } \\
\text { Motorcycle Repair }\end{array}$ & $6,121.6$ & 1.17 & 1.21 & -0.04 & 400.0 \\
\hline $\begin{array}{l}\text { Transportation and } \\
\text { Warehousing }\end{array}$ & $2,702.3$ & 1.33 & 1.21 & 0.12 & 323.93 \\
\hline $\begin{array}{l}\text { Provision of } \\
\text { Accommodation and } \\
\text { Food and Drink }\end{array}$ & 318.3 & 1.22 & 1.21 & 0.01 & 3.31 \\
\hline $\begin{array}{l}\text { Information and } \\
\text { Communication }\end{array}$ & $4,595.3$ & 1.40 & 1.21 & 0.19 & 874.68 \\
\hline $\begin{array}{l}\text { Financial Services and } \\
\text { Insurance }\end{array}$ & $2,058.3$ & 1.30 & 1.21 & 0.09 & 181.44 \\
\hline Real Estate & $1,402.8$ & 1.17 & 1.21 & -0.04 & $\overline{57.4}$ \\
\hline Company Services & 157.7 & 2.18 & 1.21 & 0.97 & 152.44 \\
\hline $\begin{array}{l}\text { Mandatory Government } \\
\text { Administration, Defense } \\
\text { and Social Security }\end{array}$ & $6,785.7$ & 1.18 & 1.21 & -0.03 & \\
\hline Education Services & $4,753.5$ & 1.22 & 1.21 & 0.01 & 30.60 \\
\hline $\begin{array}{l}\text { Health Services and } \\
\text { Social Activities }\end{array}$ & $1,148.8$ & 1.28 & 1.21 & 0.07 & 83.74 \\
\hline Other services & $1,172.2$ & 1.38 & 1.21 & 0.17 & 201.77 \\
\hline TOTAL & $54,108.0$ & 21.81 & 20.59 & 1.22 & 624.41 \\
\hline
\end{tabular}

Source: Processed Secondary Data in 2020

Based on the calculation of the Proportional Shift value in table 9 above, it is known that the areas with red shading indicate that the sectors in NTT Province are growing slower than the proportion of their national growth, according to the Proportional Shift analysis it is known that there are 7 sectors in NTT Province which are slower than the national region. namely the agriculture, forestry and fisheries sector, the mining and quarrying sector, the processing industry sector, the electricity and gas supply sector, the wholesale and retail trade sector; Car and Motorcycle Repair, Real Estate sector and Mandatory Government Administration, Defense and Social Security sector. Meanwhile, the sectors that are shaded in white indicate that the sector has higher growth compared to the national territory. 


\section{Differential Shift (D) calculation}

After knowing the Proportional Shift value, the Differential Shift value will be calculated. This component measures the magnitude of the Net Regional Shift caused by certain sectors that are growing faster and slower in the region concerned than at the national level due to internal local factors. The following is the result of the data processing of the Differential Shift value in table 10 below:

Table 10. The results of the calculation of the value of the Differential Shift (D) in NTT Province in 2014-2018

\begin{tabular}{|c|c|c|c|c|c|}
\hline \multirow{2}{*}{$\begin{array}{l}\text { Economic Sector by } \\
\text { Business Field }\end{array}$} & Er, $\mathbf{i}, \mathrm{t}$ & EN, i, t / EN, i, tn & $\mathrm{Er}, \mathrm{i}, \mathrm{tn}$ & (b) $\times(c)$ & $\begin{array}{c}\text { Differential } \\
\text { Shift }\end{array}$ \\
\hline & (a) & (b) & (c) & (d) & (a) - (d) \\
\hline $\begin{array}{l}\text { Agriculture, Forestry and } \\
\text { FisherAies }\end{array}$ & $17,875.7$ & 1.16 & $15,614.0$ & 18075,2407 & \\
\hline Mining and excavation & 913.3 & 1.00 & 794.6 & 796,6158 & 116.7 \\
\hline Processing industry & 841.4 & 1.18 & 674.6 & 797,9356 & 43.5 \\
\hline $\begin{array}{l}\text { Procurement of } \\
\text { Electricity and Gas }\end{array}$ & 51.7 & 1.14 & 35.8 & 40,7720 & 10.9 \\
\hline $\begin{array}{l}\text { Water Supply, Waste } \\
\text { Management, Waste and } \\
\text { Recycling }\end{array}$ & 42.9 & 1.22 & 39.2 & 47.9672 & \\
\hline Construction & $7,254.9$ & 1.27 & $5,733.4$ & 7269.4949 & \\
\hline $\begin{array}{l}\text { Wholesale and Retail } \\
\text { Trade; Car and } \\
\text { Motorcycle Repair }\end{array}$ & $7,772.4$ & 1.17 & $6,121.6$ & 7159,6686 & 612.7 \\
\hline $\begin{array}{l}\text { Transportation and } \\
\text { Warehousing }\end{array}$ & $3,527.9$ & 1.33 & $2,702.3$ & 3597.0711 & \\
\hline $\begin{array}{l}\text { Provision of } \\
\text { Accommodation and } \\
\text { Food and Drink }\end{array}$ & 492.8 & 1.22 & 318.3 & 388,8449 & 104.0 \\
\hline $\begin{array}{l}\text { Information and } \\
\text { Communication }\end{array}$ & $5,794.3$ & 1.40 & $4,595.3$ & 6440.6960 & \\
\hline $\begin{array}{l}\text { Financial Services and } \\
\text { Insurance }\end{array}$ & $2,585.8$ & 1.30 & $2,058.3$ & 2674.5412 & \\
\hline Real Estate & $1,657.9$ & 1.17 & $1,402.8$ & 1641.6680 & 16.2 \\
\hline Company Services & 175.0 & 2.18 & 157.7 & 343.4575 & \\
\hline $\begin{array}{l}\text { Mandatory Government } \\
\text { Administration, Defense } \\
\text { and Social Security }\end{array}$ & $8,468.8$ & 1.18 & $6,785.7$ & 8003,4061 & 465.4 \\
\hline Education Services & $5,572.4$ & 1.22 & $4,753.5$ & 5788,2356 & \\
\hline $\begin{array}{l}\text { Health Services and } \\
\text { Social Activities }\end{array}$ & $1,480.3$ & 1.28 & $1,148.8$ & 1475.2149 & 5.1 \\
\hline Other services & $1,434.0$ & 1.38 & $1,172.2$ & 1621.5893 & 01. \\
\hline TOTAL & $65,941.4$ & 21.81 & $54,108.0$ & 66162.4194 & -220.9194 \\
\hline
\end{tabular}

Source: Processed Secondary Data in 2020

Based on the Differential Shift analysis above, there are 8 sectors in NTT Province that are growing faster based on internal local factors, namely, the mining and quarrying sector, the manufacturing sector, the electricity and gas supply sector, the wholesale and retail 
trade sector; Car and Motorcycle repair, the provision of accommodation and food and drink sector, the real estate sector, the government administration sector, defense and compulsory social security and the health services and social activities sector, while the agriculture, forestry and fisheries sector, water supply sector, waste management, Waste and Recycling, the construction sector, the transportation and warehousing sector, the information and communication sector, the financial services and insurance sector, the corporate services sector, the education services sector and other services sectors experienced slow growth.

Checking: From the table above it can also be seen that the total value added of the NTT Province GRDP is formulated as follows:

\section{$(\Sigma$ PDRB $2018-\Sigma$ PDRB 2014 $)=65,941.4-54,108.0=11,833.4$}

Where these results will provide the same value as the calculation results of the three components of Shift and Share, namely:

$$
\Sigma(\mathrm{Ns}+\mathrm{P}+\mathrm{D})=11429.91+624.41+(-220.9194)=11,833.4
$$

The results of the Shift Share analysis above show that the added value is 11,833.4, and if the added value is compared with the value of the National Share, Proportional Shift and Defferential Shift, the added value is the same, which is $11,833.4$.

\section{Conclusion}

By using several analytical tools in this research, it can be known and analyzed the economic sectors which are the leading and the basic sectors as well as the sectoral shifts in economic development in East Nusa Tenggara Province in 2014-2018 are as follows:

1. Based on the results of the Klassen Typology analysis, the sector which is included in the advanced sector and growing rapidly or the leading sector is the sector Mandatory Government Administration, Defense and Social Security. Meanwhile, sectors that are included in the advanced but depressed sector are the Agriculture, Forestry and Fisheries sector, the Construction sector, the Transportation and Warehousing sector, the Information and Communication sector, the Education Services sector, the Health Services sector and Social Activities and the Other Services sector. Sectors classified as potential or still developing sectors are mining and quarrying sector, processing industry sector, electricity and gas supply sector, wholesale and retail trade: car and motorcycle repair and accommodation and food and drink provision sector. Meanwhile, sectors that are relatively lagging behind are the water supply sector, waste management, waste and recycling, the financial services and insurance sector, the real estate sector and the corporate services sector.

2. Based on the results of the Location Quotient analysis, it can be seen that which are the basic sectors in East Nusa Tenggara Province, namely the Agriculture, Forestry and Fisheries sector, the Construction sector, the Transportation and Warehousing sector, the Information and Communication sector, the Government Administration, Defense and Compulsory Social Security sector. Education Services, Health Services and Social Activities and Other Services sectors.

3. Based on the results of the Shift Share analysis, the sectors that have the largest National Share value are the sectors of Agriculture, Forestry and Fisheries, while the smallest values are the sectors of Water Supply, Waste Management, Waste and Recycling. According to the Proportional Shift analysis, it is known that there are 7 sectors in NTT Province that are slower than the national territory, namely the Agriculture, Forestry and Fisheries sector, 
the Mining and Excavation sector, the Processing Industry sector, the Electricity and Gas Supply sector, the Wholesale and Retail Trade sector; Car and Motorcycle Repair, Real Estate sector and Mandatory Government Administration, Defense and Social Security sector. Based on the Differential Shift analysis, it is known that there are 8 sectors in NTT Province that are growing faster based on internal local factors, namely, mining and quarrying sector, processing industry sector, electricity and gas supply sector, wholesale and retail trade sector; Car and motorcycle repair, the provision of accommodation and food and drink sector, the real estate sector, the government administration sector, defense and compulsory social security and the health services and social activities sector.

\section{References}

Amir, Amri, 2007. Perekonomian Indonesia (dalam perspektif makro). Biografika:Bogor.

Ambardi, Urbanus M dan Socia Prihawantoro, 2002. Pengembangan Wilayah dan Otonomi

Daerah. Pusat pengkajian kebijakan pengembangan wilayah (P2KTPW - BPPT). Jakarta

Bayu Kharisma, Ferry Hadiyanto, 2018. Penentuan Potensi Sektor Unggulan Dan Potensial Di Provinsi Maluku. Jurnal Ekonomi \& Studi Pembangunan, Volume 19, Nomor 1.

Badan Pusat Statistik (BPS). Provinsi Nusa Tenggara Timur Dalam Angka 2018.

Badan Pusat Statistik (BPS). Provinsi Nusa Tenggara Timur Dalam Angka 2019.

Badan Pusat Statistik (BPS). Statistik Indonesia 2018.

Badan Pusat Statistik (BPS). Statistik Indonesia 2019.

Departemen Pertanian, 2005. Landasan Teoritis dan Fakta Empiris. Diakses pada tanggal 22 Juli 2020, dari http://www.deptan.go.id/konsep/landasan.htm.

Dewi Sondari, 2007. Analisis Sektor Unggulan Dan Kinerja Ekonomi Provinsi Jawa Barat. Skripsi Pascasarjana Institut Pertanian Bogor Fakultas Ekonomi Dan Manajemen.

Evie Erviana, 2020. Analisis Sektor Unggulan dan Sektor Potensial Dalam Meningkatkan Pertumbuhan Ekonomi Kabupaten Mesuji Dalam Persepektif Ekonomi Islam. Skripsi Pascasarjana Universitas Islam Negeri Raden Intan Lampung.

Glasson, J. 1977. Pengantar Perencanaan Regional. Terjemahan Paul Sitohang. Fakultas Ekonomi Universitas Indonesia. Jakarta.

Hadi, Sasana, 2006. Analisis Dampak Transfer Pemerintah Terhadap Kinerja Fiskal di Kab/Kota Di Provinsi Jateng Dalam Pelaksanaan Desentralisasi Fiskal, Jurnal Ekonomi Pembangunan, Vol. 7, No. 2.

Ismail Ibrahim, 2018. Analisis Potensi Sektor Ekonomi Dalam Upaya Peningkatan Pertumbuhan Ekonomi (Studi Empiris Pada Kabupaten dan Kota di Provinsi Gorontalo Tahun 2012-2016). Gorontalo Development Review, P-ISSN: 2614-5170, EISSN: 2615-1375, Volume 1 - NO.1.

Isma'il, M., Santosa, D.B. \& Yustika, A.E. 2015. Sistem ekonomi Indonesia: tafsiran Pancasila \& UUD 1945. Jakarta: Penerbit Erlangga.

Jhingan, M.L, 2014. Ekonomi Pembangunan dan Perencanaan. Cetakan k Jakarta: Rajawali Pers.

Kalzum R. Jumiyanti, 2018. Analisis Location Quotient dalam Penentuan Sektor Basis dan Non Basis di Kabupaten Gorontalo. Gorontalo Development Review, Vol. 1, NO. 1, PISSN: 2614-5170, EISSN: 2615-1375, 2018.

http://jurnal.unigo.ac.id/index.php/gdrev/article/download/112/109 (diakses pada tanggal 29 Juni 2020)

Lincolin, Arsyad, 1999. Ekonomi Pembangunan. Yogyakarta: Badan Penerbit STIE YKPN.

Lincolin, Arsyad, 2000. Pengantar Perencanaan dan Pebangunan Ekonomi Daerah. UGM, Yogyakarta. 
Lincolin, Arsyad, 2010. Ekonomi Pembangunan, Yogyakarta: Unit Penerbit Dan Percetakan STIM YKPN Yogyakarta.

Nalle, Frederic. 2018. Analisis Pertumbuhan Ekonomi Inklusif Kabupaten Timor Tengah Utara. Jurnal Agribisnis Lahan Kering. Universitas Timor. International Standard of Serial Number 2502-1710.

Richardson, Harry W, 2001. Dasar-Dasar Ilmu Ekonomi Regional, Terjemahan Paul Sitohang Edisi Revisi. Jakarta : FE UI.

Saberan, H, 2002. Produk Domestik Regional Bruto, Rajawali, Jakarta.

Saharuddin, S. 2005. Pengaruh perkembangan Ekonomi Terhadap Penerimaan APBD dan kesejahteraan Rakyat di Wilayah Sulawesi Selatan. Di sertai tidak di terbitkan. Makassar: Program Pasacasarjana-UNHAS.

Setiawan, Darma, I dewa Made, 2006. Peranan Sektor Unggulan Terhadap Pertumbuhan Ekonomi Daerah Jawa Timur, Bali dan NTB: Pendekatan Input Output Multiregional. Universitas Warmadewa, Denpasar.

Sjafrizal, 2008. Ekonomi Regional, Teori dan Aplikasi, Baduose Media, Cetakan Pertama, Padang.

Sudirman, M. Alhudori, 2018. Analisis Sektor Unggulan dalam Meningkatkan Perekonomian dan Pembangunan Wilayah Provinsi Jambi. Jurnal Manajemen dan Sains (JMAS) Vol.3 No.1.

Sugiyono, 2008. Metode Penelitian Bisnis. Bandung: CV Alfabeta

Sukirno, Sadono, 2006. Makro Ekonomi Teori Pengantar. Jakarta: Raja Grafindo Persada.

Sukirno, Sadono, 1994. Pengantar Makro Ekonomi, Edisi Kedua, Raja Grafindo Persada, Jakarta.

Tarigan, Robinson, 2005. Ekonomi Regional Teori dan Aplikasi. Jakarta : PT. Bumi Aksara.

Trias Dian Suciati, 2017. Analisis Sektor Unggulan Dalam Meningkatkan Perekonomian Kabupaten Pacitan Tahun 2011-2015. Universitas Muhammadiyah Surakarta.

Undang-Undang Republik Indonesia Nomor 32 Tahun 2004 Tentang Pemerintahan Daerah. Untoro, Joko, 2010. Ekonomi Makro. Jakarta: Kawah Media.

Usya, N, 2006. Analisis Struktur Ekonomi dan Identifikasi Sektor Unggulan di Kabupaten Subang. Skripsi, Fakultas Ekonomi dan Manajemen. IPB. Bogor.

Vicky Y. Takalumang, Vekie A. Rumat e, Agnes L.Ch.P Lapian, 2018. Analisis Sektor Ekonomi Unggulan Dalam Mendorong Pertumbuhan Ekonomi Kabupaten/Kepulauan Sangihe. Jurnal Berkala Ilmiah Efisiensi, Vol. 18 No. 01.

Widodo, Tri, 2006. Perencanaan Pembangunan Aplikasi Komputer. UPP STIM YKPN Yogyakarta.

Yuni Purnama, Muhammad Nurjihadi, Fitriah Permata Cita, 2017. Analisis Sektor Unggulan Dan Pergeseran Struktur Dalam Meningkatkan Pertumbuhan Ekonomi NTB 20002015. Jurnal Ekonomi dan Bisnis Indonesia, Vol. 02, No. 02 pp. 37-45.

Yunita Wiandari, 2018. Analisis Sektor Unggulan Wilayah Dalam Meningkatkan Pertumbuhan Ekonomi di Kabupaten Kebumen Tahun 2010-2016. Jurnal ekonomi pembangunan edisi, volume. 